\title{
Respons Hasil dan Kualitas Hasil Unpollinated Tomat Beef Kultivar Umagna terhadap Jenis dan Konsentrasi ZPT (GA3 dan 4-CPA) di Dataran Medium
}

\author{
Nedya Deninta ${ }^{1}$, Kusumiyati ${ }^{2}$, dan Syariful Mubarok ${ }^{2}$ \\ ${ }^{1}$ Program Studi Agronomi, Fakultas Pertanian, Universitas Padjadjaran \\ ${ }^{2}$ Departemen Budidaya, Fakultas Pertanian, Universitas Padjadjaran \\ Jalan Raya Bandung-Sumedang Km 21 \\ *Alamat korespondensi: nedya12001@mail.unpad.ac.id
}

\begin{abstract}
The responses of parthenocarpy fruit formation, yield, and yield quality with different types and concentrations of PGR (GA3 and 4-CPA) for unpollinated beef tomato Cv. Umagna in medium elevation
\end{abstract}

Beef tomato is loved for its large size and high economic value. The issues of tomatoes production in medium elevation is the enhancement of fruit abortion, it leads to the reduction of fruit set percentage. High temperature can lead to failure of fertilization and it can be coped by Plant Growth Regulator application (GA3 and 4-CPA). Parthenocarpy fruit can also be obtained by $\mathrm{GA}_{3}$ and 4-CPA, both of them can impact cell division and cell enlargement. The experiment was carried out to study about the effect of different types and concentrations of plant growth regulator for parthenocarpy fruit formation, yield, and yield quality of beef tomato Cv. Umagna. The experiment was conducted at Controlled Cultured Laboratory, Agriculture Faculty, Universitas Padjadjaran, Jatinangor. The experiment was carried out to study about the effect of different types and concentrations of plant growth regulator for yield and yield quality of beef tomato Cv. Umagna. The experimental design used was Split plot with three times replications. The main plot was type of Plant Growth Regulator, comprised of GA3 and 4-CPA. Meanwhile, the subplot was concentration of Plant Growth Regulator with four levelsof 0, 15, 45, and $90 \mathrm{ppm}$. The result showed that there were interactions between types and concentrations of PGR in weight and number of fruits per plot and pericarp thickness. The $90 \mathrm{ppm}$ concentration of PGR gave the same value with $15 \mathrm{ppm}$ and $45 \mathrm{ppm}$ for the percentage of weight and number of A and B's quality.

Keywords: Beef tomato, Concentration, GA3, 4-CPA, Phartenocarpy

\begin{abstract}
ABSTRAK
Tomat beef disukai karena ukuran buahnya yang besar dan memiliki nilai ekonomis yang tinggi. Permasalahan tomat di dataran medium yaitu peningkatan gugur buah sehingga menurunkan persentase fruit set. Permasalahan suhu tinggi di dataran medium yang menimbulkan kegagalan fertilisasi dapat diatasi dengan aplikasi zat pengatur tumbuh (GA3 and 4-CPA). Pembentukan buah partenokarpi juga dapat memengaruhi pembelahan dan pemanjangan sel. Percobaan ini bertujuan untuk mempelajari jenis dan konsentrasi ZPT terhadap hasil dan kualitas hasil buah partenokarpi tomat beef kultivar Umagna. Penelitian dilaksanakan di Laboratorium Kultur Terkendali, Fakultas Pertanian, Universitas Padjadjaran di Jatinangor. Rancangan Percobaan yang digunakan adalah Rancangan Petak Terbagi dengan tiga ulangan. Petak utama adalah jenis ZPT dengan dua taraf yaitu GA3 dan 4-CPA serta anak petak yang merupakan konsentrasi ZPT dengan empat taraf yaitu $0,15,60$, dan $90 \mathrm{ppm}$. Hasil penelitian menunjukkan terjadi interaksi antara jenis dan konsentrasi ZPT terhadap bobot, jumlah buah serta ketebalan pericarp. ZPT konsentrasi 90 ppm menghasilkan hasil persentase bobot dan jumlah kualitas A dan B seperti konsentrasi 15 ppm dan 45 ppm.

Kata Kunci: GA3, 4-CPA, Konsentrasi, Partenokarpi, Tomat beef
\end{abstract}




\section{PENDAHULUAN}

Salah satu jenis tomat yang mempunyai beberapa keunggulan yaitu tomat beef atau tomat apel. Tomat beef banyak dikonsumsi segar dan memiliki kelebihan seperti ukuran buah yang besar (220-240 g) dan seragam, memiliki jumlah biji yang lebih sedikit, berdaging tebal, produksi konsisten sepanjang musim, serta penampilannya yang menarik (Onggo dkk., 2015). Produksi tomat pada tahun 2015 menurun menjadi 877.801 ton dibandingkan dengan produksi di tahun 2014 yang mencapai 916.001 ton. Hal tersebut menunjukkan bahwa terjadi penurunan produksi pada kedua tahun tersebut sebesar 3,82\% (BPS, 2015). Akan tetapi, produksi dan produktivitas tomat beef di Indonesia belum diketahui secara pasti.

Tomat beef biasanya ditanam di dataran tinggi sehingga penanaman di dataran medium dapat menurunkan produksi tanaman. Penurunan produksi ini berkaitan dengan peningkatan gugur bunga atau buah yang dapat menurunkan persentase fruit set. Hal tersebut terjadi karena fruit set sangat bergantung kepada keberhasilan penyerbukan (Choudhury et al., 2013). Peningkatan produksi tomat di dataran medium dapat diatasi dengan menggunakan zat pengatur tumbuh. Ada beberapa jenis hormon eksogen yang dapat diaplikasikan ke tanaman diantaranya adalah $\mathrm{GA}_{3}$ dan 4-CPA. Pengaruh lain yang diberikan ZPT (GA3 dan 4-CPA) selain meningkatkan produksi tanaman yaitu menghasilkan buah partenokarpi. Partenokarpi merupakan proses terbentuknya buah tanpa melalui proses fertilisasi, di mana buah yang terbentuk secara pertenokarpi biasanya menghasilkan biji yang lebih sedikit atau bahkan tidak membentuk biji dan memiliki daya simpan yang lebih lama (Adnyesuari, 2015). Percobaan ini dilakukan dengan memberikan zat pengatur tumbuh seperti $\mathrm{GA}_{3}$ dan 4-CPA dengan tujuan dapat menghasilkan buah partenokarpi yang memengaruhi hasil dan kualitas hasil tanaman tomat beef kultivar Umagna unpollinated.

\section{BAHAN DAN METODE}

Percobaan dilakukan di dalam rumah plastik Laboratorium Kultur Terkendali Fakultas Pertanian Universitas Padjadjaran, dengan ketinggian tempat $730 \mathrm{~m}$ di atas permukaan laut, dilaksanakan dari bulan Maret sampai bulan Mei 2019. Rancangan percobaan yang digunakan yaitu Rancangan Petak Terbagi. Petak utama (main plot) yaitu jenis ZPT, sedangkan anak petak (sub plot) yaitu konsentrasi ZPT. Faktor pertama adalah J (jenis ZPT) terdiri dari 2 taraf yaitu j1 (GA3) dan j2 (4-CPA). Faktor kedua adalah K (konsentrasi ZPT) terdiri dari 4 taraf yaitu $\mathrm{k}_{1}(0 \mathrm{ppm}), \mathrm{k}_{2}(15 \mathrm{ppm}), \mathrm{k}_{3}$ (45 ppm), dan $\mathrm{k}_{4}$ (90 ppm). Jumlah sampel tiap plot empat tanaman untuk pengamatan pertumbuhan dan data hasil diambil dari keseluruhan tanaman dalam plot.

Bahan-bahan yang digunakan dalam percobaan ini terdiri dari bibit tomat beef kultivar Umagna, hormon sintetik $\mathrm{GA}_{3}$ Sun Rise (bahan aktif $1 \mathrm{~g} \mathrm{GA}_{3}=10 \%$ ), hormon sintetik 4-CPA (bahan aktif 4-CPA $0,15 \%$ dalam $20 \mathrm{~mL}$ ). Tomat ditanam di tanah yang telah dicampur dengan pupuk kotoran sapi dan arang sekam. Aplikasi ZPT dilakukan sebanyak 2 kali, penyemprotan pertama dilakukan tepat setelah emaskulasi, sedangkan aplikasi selanjutnya dilakukan 4 hari setelah aplikasi ZPT pertama. Teknik penyemprotan dilakukan dengan mengarahkan nozzle ke putik bunga secara perlahan (pollen sudah diemaskulasi).

Variabel hasil dan kualitas hasil yang diamati meliputi bobot dan jumlah buah partenokarpi, persentase bobot dan jumlah kualitas A (bobot $>150 \mathrm{~g}$, bentuk simetris, dan kecacatan $0 \%$, B (bobot $>120-<150 \mathrm{~g}$, bentuk simetris, kecacatan $<5 \%$ ), dan C (bobot bobot $>110-<120 \mathrm{~g}$, bentuk simetris, kecacatan $<10 \%$ ), dan ketebalan pericarp. Untuk mengetahui pengaruh perlakuan yang diberikan, digunakan uji $\mathrm{F}$ dengan taraf nyata $5 \%$, sedangkan untuk menguji perbedaan nilai ratarata perlakuan dilakukan dengan uji Duncan pada taraf nyata $5 \%$.

\section{HASIL DAN PEMBAHASAN}

\section{Bobot Buah (g) dan Jumlah Buah (Butir) dari Tandan Ke 2-4 yang Diberi Perlakuan Emaskulasi}

Hasil analisis statistik menunjukkan bahwa terjadi interaksi antara jenis dan konsentrasi ZPT terhadap bobot dan jumlah buah (tandan 2 hingga tandan 4). Pengaruh interaksi dari jenis dan konsentrasi ZPT terhadap bobot dan jumlah buah dari tandan 2-4 yang diberi perlakuan emaskulasi dapat dilihat pada Tabel 1 dan 2. Tabel 1 dan 2 menunjukkan bahwa $\mathrm{GA}_{3}$ dan 4-CPA 90 ppm menghasilkan bobot dan jumlah buah tertinggi dibandingkan dengan perlakuan lainnya. $\mathrm{GA}_{3}$ menghasilkan bobot dan jumlah buah yang lebih tinggi meskipun dengan konsentrasi yang lebih rendah dibandingkan dengan 4-CPA. 
Tabel 1. Pengaruh jenis dan konsentrasi ZPT terhadap bobot buah dari tandan ke 2-4 yang diberi perlakuan emaskulasi

\begin{tabular}{ccc}
\hline & \multicolumn{2}{c}{$\begin{array}{c}\text { Bobot buah dari tandan ke 2-4 yang } \\
\text { diberi perlakuan emaskulasi (g) }\end{array}$} \\
\cline { 2 - 3 } Zonsentrasi $(\mathrm{ppm})$ & \multicolumn{3}{c}{ Jenis ZPT } \\
\cline { 2 - 3 } & $\mathrm{GA}_{3}$ & $4-\mathrm{CPA}$ \\
\hline 0 & $0,00 \mathrm{a}$ & $0,00 \mathrm{a}$ \\
& $\mathrm{A}$ & $\mathrm{A}$ \\
15 & $718,00 \mathrm{~b}$ & $600,75 \mathrm{~b}$ \\
& $\mathrm{~A}$ & $\mathrm{~A}$ \\
45 & $905,00 \mathrm{c}$ & $621,42 \mathrm{~b}$ \\
& $\mathrm{~B}$ & $\mathrm{~A}$ \\
90 & $1149,17 \mathrm{~d}$ & $812,75 \mathrm{c}$ \\
& $\mathrm{B}$ & $\mathrm{A}$
\end{tabular}

Keterangan: Angka yang diikuti dengan huruf kecil yang sama ke arah vertikal dan oleh huruf besar yang sama ke arah horizontal menunjukkan tidak berbeda nyata menurut uji jarak berganda Duncan 5\%. Perlakuan 0 ppm merupakan tanaman yang diemaskulasi namun tidak diberi ZPT sehingga tidak menghasilkan buah.

Bobot buah dipengaruhi oleh beberapa faktor yang mendukung yaitu cahaya, suhu, ketersediaan nutrisi, dan serangan hama dan penyakit. Pemberian ZPT auksin atau GA dapat menginduksi pembentukan buah partenokarpi. Hal tersebut ditunjukkan dengan adanya pemicuan dalam pembelahan dan pemanjangan sel selama perkembangan ovarium pada jalur sinyal molekuler, sehingga terbentuklah buah partenokarpi yang disebabkan oleh aktivitas ini. Hasil penelitian Ullah et al. (2014) menunjukkan bahwa aplikasi GA3 30 ppm dapat meningkatkan bobot tanaman tertinggi $(0,1389 \mathrm{~kg})$ setelah disemprotkan pada beberapa kultivar jeruk manis sebelum berbunga. Pemberian ZPT merupakan faktor yang dapat memengaruhi hasil tanaman tersebut karena kedua hormon ini meningkatkan fruit set, menurunkan gugur buah, sehingga meningkatkan bobot buah dan kemudian meningkatkan hasil per tanaman. Pemberian $\mathrm{GA}_{3}$ pada tanaman akan meningkatkan kandungan auksin melalui pembentukan enzim proteolitik yang akan membebaskan senyawa triptophan sebagai prekursor auksin, sehingga berpengaruh kepada pertumbuhan dan perkembangan tanaman (Choudhary et al., 2002).

$\mathrm{GA}_{3}$ merupakan salah satu hormon yang bermanfaat dalam perombakan karbohidrat menjadi senyawa-senyawa yang lebih sederhana seperti sukrosa dengan cara mengaktifkan enzim sukrosaphospate-syntase (SPS). Enzim ini berperan dalam pembentukan sukrosa dari triose-P yang dapat diangkut ke bagian tanaman lain, salah satunya menuju organ generatif (Das et al., 2015). Penelitian pada jeruk mandarin menunjukkan bobot buah jeruk mandarin terbesar diperoleh pada perlakuan GA3 20 ppm (128,6 g) dibandingkan dengan kontrol $(95,51 \mathrm{~g})$. Konsentrasi GA3 yang paling efektif untuk perkembangan buah jeruk mandarin ini yaitu 10-20 ppm. Perkembangan buah yang telah diaplikasikan GA3 menyebabkan peningkatan bobot buah karena adanya proses mediasi untuk translokasi dan mobilisasi fotosintat yang lebih cepat dari source (Ullah et al., 2014).

Tabel 2. Pengaruh jenis dan konsentrasi ZPT terhadap jumlah buah dari tandan 2-4 yang diberi perlakuan emaskulasi

\begin{tabular}{|c|c|c|}
\hline \multirow{3}{*}{$\begin{array}{l}\text { Konsentrasi } \\
\mathrm{ZPT}(\mathrm{ppm})\end{array}$} & \multicolumn{2}{|c|}{$\begin{array}{c}\text { Jumlah buah dari tandan } 2-4 \text { yang } \\
\text { diberi perlakuan emaskulasi }\end{array}$} \\
\hline & \multicolumn{2}{|c|}{ Jenis ZPT } \\
\hline & $\mathrm{GA}_{3}$ & 4-CPA \\
\hline \multirow[t]{2}{*}{0} & 0,00 a & $0,00 \quad \mathrm{a}$ \\
\hline & $\mathrm{A}$ & A \\
\hline \multirow[t]{2}{*}{15} & $5,67 \mathrm{~b}$ & $4,00 \mathrm{~b}$ \\
\hline & B & A \\
\hline \multirow[t]{2}{*}{45} & $6,00 \mathrm{~b}$ & $4,00 \mathrm{~b}$ \\
\hline & B & A \\
\hline \multirow[t]{2}{*}{90} & 7,33 c & $5,00 \mathrm{c}$ \\
\hline & B & A \\
\hline
\end{tabular}

$\overline{\text { Keterangan: Angka yang diikuti dengan huruf kecil yang sama ke }}$ arah vertikal dan oleh huruf besar yang sama ke arah horizontal menunjukkan tidak berbeda nyata menurut uji jarak berganda Duncan 5\%. Perlakuan 0 ppm merupakan tanaman yang diemaskulasi namun tidak diberi ZPT sehingga tidak menghasilkan buah.

Aplikasi GA3 30 ppm menghasilkan jumlah buah tertinggi (46,06\%) dibandingkan dengan konsentrasi $10 \mathrm{ppm}$ dan $20 \mathrm{ppm}$. Hal ini terjadi karena diduga pengaruh $\mathrm{GA}_{3}$ terhadap pertumbuhan buah optimal pada konsentrasi lebih tinggi. Pembentukan buah tomat diatur oleh konsentrasi hormon yang optimal dan cadangan karbohidrat yang cukup, sehingga terjadi peningkatan jumlah buah yang dihasilkan (Singh et al., 2019). GA3 berperan meningkatkan jumlah buah melalui penggandaan dan pemanjangan sel meristem yang memberikan pengaruh positif terhadap penurunan gugur buah dan peningkatan jumlah buah per tanaman (Sarkar \& Ghosh, 2005).

Menurut Karim et al. (2015), aplikasi 4-CPA pada berbagai konsentrasi dapat meningkatkan jumlah buah tomat kultivar BARI Hybrid-4 and BARI Hybrid-8 secara signifikan. Jumlah buah 
tertinggi diperoleh pada konsentrasi 60 ppm $(24,97)$, sedangkan jumlah buah terendah diperoleh dari perlakuan kontrol. Suhu tinggi menyebabkan berkurangnya kandungan auksin dan giberelin terutama saat pembentukan bunga dan perkembangan buah, sehingga penambahan hormon ekstrogen dari luar dapat memengaruhi jumlah buah per tanaman.

Persentase Bobot dan Jumlah Buah Berdasarkan Kelas Kualitas A, B, dan C
Hasil analisis statistik menunjukkan bahwa tidak terjadi interaksi antara jenis dan konsentrasi ZPT terhadap persentase bobot dan jumlah buah kualitas A, B, dan C. Pengaruh jenis dan konsentrasi ZPT terhadap persentase bobot dan jumlah buah berdasarkan kelas kualitas A, B, dan C dan dapat dilihat pada Tabel 3. Tabel 3 menunjukkan bahwa konsentrasi ZPT 15, 45, dan 90 ppm dapat meningkatkan persentase bobot dan jumlah kualitas kelas A, sedangkan konsentrasi $15 \mathrm{ppm}$ dapat meningkatkan kualitas kelas B.

Tabel 3. Pengaruh jenis dan konsentrasi ZPT terhadap persentase bobot dan jumlah buah kualitas A, B dan C

\begin{tabular}{|c|c|c|c|c|c|c|}
\hline \multicolumn{7}{|c|}{ Persentase bobot dan jumlah buah kualitas A, B, dan C (\%) } \\
\hline \multirow{2}{*}{ Perlakuan } & \multicolumn{3}{|c|}{ Bobot buah } & \multicolumn{3}{|c|}{ Jumlah buah } \\
\hline & A & $\mathrm{B}$ & $\mathrm{C}$ & A & $\mathrm{B}$ & $\mathrm{C}$ \\
\hline \multicolumn{7}{|l|}{ Jenis ZPT (J) } \\
\hline $\mathrm{j}_{1}=\mathrm{GA}_{3}$ & 69,98 a & 29,06 a & 0,96 a & 63,60 a & 34,30 a & $2,10 \mathrm{a}$ \\
\hline $\mathrm{j}_{2}=4-\mathrm{CPA}$ & 88,56 a & $10,31 \mathrm{a}$ & $1,13 \mathrm{a}$ & $84,54 \mathrm{a}$ & 13,87 a & $1,59 \mathrm{a}$ \\
\hline \multicolumn{7}{|c|}{ Konsentrasi ZPT (K) } \\
\hline $\mathrm{k}_{1}=0 \mathrm{ppm}$ & $0,00 \mathrm{a}$ & $0,00 \mathrm{a}$ & $0,00 \mathrm{a}$ & $0,00 \mathrm{a}$ & $0,00 \mathrm{a}$ & $0,00 \mathrm{a}$ \\
\hline $\mathrm{k}_{2}=15 \mathrm{ppm}$ & $71,48 \mathrm{~b}$ & $26,82 \mathrm{~b}$ & $1,17 \mathrm{a}$ & $67,14 \mathrm{~b}$ & $30,48 \mathrm{~b}$ & $2,38 \mathrm{a}$ \\
\hline $\mathrm{k}_{3}=45 \mathrm{ppm}$ & $82,95 \mathrm{~b}$ & $17,05 \mathrm{ab}$ & $0,00 \mathrm{a}$ & $78,33 \mathrm{~b}$ & $21,67 \mathrm{~b}$ & $0,00 \mathrm{a}$ \\
\hline $\mathrm{k}_{4}=90 \mathrm{ppm}$ & $82,93 \mathrm{~b}$ & $15,19 \mathrm{ab}$ & $1,88 \mathrm{a}$ & $76,75 \mathrm{~b}$ & $20,11 \mathrm{~b}$ & $3,14 \mathrm{a}$ \\
\hline
\end{tabular}

Keterangan: Nilai rata-rata yang diikuti oleh huruf yang sama pada kolom yang sama, menunjukkan tidak berbeda nyata berdasarkan uji Jarak Berganda Duncan 5\%. Perlakuan 0 ppm merupakan tanaman yang diemaskulasi namun tidak diberi ZPT sehingga tidak menghasilkan buah.

Tabel 4. Pengaruh jenis dan konsentrasi ZPT terhadap ketebalan pericarp

\begin{tabular}{|c|c|c|}
\hline \multirow{3}{*}{$\begin{array}{l}\text { Konsentrasi } \\
\text { ZPT (ppm) }\end{array}$} & \multicolumn{2}{|c|}{ Ketebalan pericarp $(\mathrm{mm})$} \\
\hline & \multicolumn{2}{|c|}{$\begin{array}{l}\text { Jenis ZPT } \\
\end{array}$} \\
\hline & $\mathrm{GA}_{3}$ & 4-CPA \\
\hline 0 & $0,00 \quad \mathrm{a}$ & $0,00 \mathrm{a}$ \\
\hline & A & A \\
\hline 15 & $\begin{array}{r}6,85 \mathrm{~b} \\
\mathrm{~A}\end{array}$ & $\begin{array}{r}7,87 \quad b \\
\text { B }\end{array}$ \\
\hline 45 & $\begin{array}{r}7,35 \quad \mathrm{c} \\
\mathrm{A}\end{array}$ & $\begin{array}{c}8,08 \text { bc } \\
\text { B }\end{array}$ \\
\hline 90 & $\begin{array}{r}8,57 \mathrm{~d} \\
\mathrm{~A}\end{array}$ & $\begin{array}{r}8,35 \quad \mathrm{c} \\
\mathrm{A}\end{array}$ \\
\hline
\end{tabular}

Keterangan: Angka yang diikuti dengan huruf kecil yang sama ke arah vertikal dan oleh huruf besar yang sama ke arah horizontal menunjukkan tidak berbeda nyata menurut uji jarak berganda Duncan 5\%. Perlakuan 0 ppm merupakan tanaman yang diemaskulasi namun tidak diberi ZPT sehingga tidak menghasilkan buah.

Menurut Naeem et al. (2001), aplikasi ZPT dapat memengaruhi setiap aspek pertumbuhan dan perkembangan tanaman, bergantung kepada konsentrasi dan organ targetnya. Gunawan dkk. (1986) menyebutkan bahwa pemberian GA3 dengan konsentrasi yang sesuai dapat memengaruhi proses biokimia dalam tanaman, sehingga proses fotosintesis meningkat dan fotosintatnya dapat digunakan untuk menentukan kebutuhan dalam proses pembentukan organ generatif hingga tanaman dapat dipanen. Pemberian giberelin dengan konsentrasi yang tepat dapat mengakibatkan kegiatan metabolisme dan laju fotosintesis meningkat, sehingga mampu meningkatkan karbohidrat yang berperan untuk perkembangan tanaman.

\section{Ketebalan Pericarp}

Hasil analisis statistik menunjukkan bahwa terjadi interaksi antara jenis dan konsentrasi ZPT terhadap ketebalan pericarp. Pengaruh interaksi dari jenis dan konsentrasi ZPT terhadap ketebalan pericarp dapat dilihat pada Tabel 4 dan Gambar 1. Tabel 4 menunjukkan bahwa GA3 dan 4-CPA 90 ppm menghasilkan ketebalan pericarp tertinggi dibandingkan dengan seluruh perlakuan lainnya. Buah tomat disusun oleh dua atau lebih karpel, yang kemudian dipisahkan oleh septum yang berasal dari fusi dua dinding karpel yang berdekatan (pericarp). Pericarp terletak berdekatan dengan rongga buah 
(locullar cavity) yang merupakan tempat biji melekat pada plasenta yang berdekatan dengan columella (Gillapsy et al., 1993). Pericarp tersusun atas 3 bagian yaitu eksocarp, mesocarp, serta endocarp (Lemaire-Chamley et al., 2005).
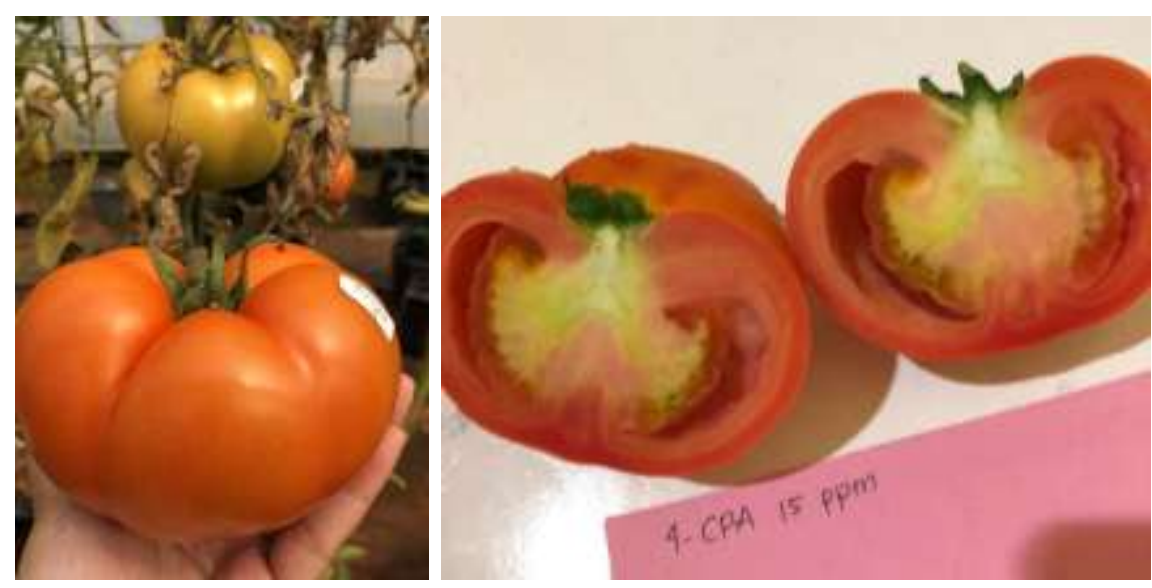

Gambar 1. Buah tomat beef kultivar Umagna yang diberi perlakuan ZPT GA3 90 ppm (kiri) dan yang diberi perlakuan 4-CPA 15 ppm (kanan).

Frekuensi pembelahan sel atau lamanya fase siklus sel mempengaruhi ukuran buah. Buah yang lebih besar mengandung lebih banyak sel daripada buah yang lebih kecil karena periode pembelahan sel yang lebih lama. Volume sel pericarp buah merah yang matang berkisar antara 2.000 dan 220.000 kali lebih besar dibandingkan dengan dinding ovarium saat pra-antesis, hal ini menunjukkan bahwa ukuran pericarp adalah salah satu penentu dalam ukuran buah (Cheniclet et al., 2005). Selain itu, ukuran buah sangat berkaitan dengan keseimbangan antara giberelin dan auksin.

Menurut Gelmesa et al., (2010), ketebalan pericarp yang lebih tinggi $(5,03 \mathrm{~mm})$ diperoleh dari interaksi GA3 20 ppm + 2,4 D 10 ppm pada tanaman tomat. Perkembangan buah maksimum berkaitan setelah pembelahan sel dan selama pemanjangan sel (Gillaspy et al., 1993). Peningkatan volume terjadi karena pemanjangan sel dapat berkontribusi kepada ukuran akhir buah. Buah tomat yang diinduksi oleh $\mathrm{GA}_{3}$ dan 2,4-D memiliki pericarp yang lebih tebal daripada buah yang diserbuki. Aplikasi gabungan dari $\mathrm{GA}_{3}$ dan 2,4-D memiliki pengaruh yang lebih baik pada ketebalan dan jumlah lapisan pericarp dibandingkan dengan aplikasi mandiri keduanya. Oleh karena itu, peningkatan ketebalan pericarp buah ini memiliki keuntungan untuk membantu kulit buah menjadi lebih tahan terhadap memar mekanis, serangan hama dan umur simpan yang lebih baik karena berkurangnya tingkat kehilangan air (Serrani et al., 2007). Menurut Kishor et al. (2017), ketebalan pericarp tertinggi pada buah delima diperoleh dari aplikasi GA3 75 ppm (4,95 $\mathrm{mm}$ ) karena $\mathrm{GA}_{3}$ mampu meningkatkan ketebalan kutikula buah dan lapisan epidermis. Hasil induksi $\mathrm{GA}_{3}$ juga menghasilkan pericarp yang lebih tebal pada buah tomat dibandingkan dengan buah yang dihasilkan secara polinasi (Serrani et al., 2007).

\section{SIMPULAN}

Berdasarkan hasil pengamatan, perlakuan $\mathrm{GA}_{3} 90 \mathrm{ppm}$ dan 4-CPA 90 ppm dapat memberikan pengaruh interaksi terhadap bobot dan jumlah buah partenokarpi serta ketebalan pericarp. Konsentrasi zat pengatur tumbuh $15 \mathrm{ppm}, 45 \mathrm{ppm}$, dan $90 \mathrm{ppm}$ memengaruhi persentase bobot dan jumlah kualitas A dan B.

\section{UCAPAN TERIMA KASIH}

Ucapan terima kasih saya berikan kepada Ibu Kusumiyati, S.P., M.Agr.Sc., Ph.D. dan Bapak Syariful Mubarok, S.P., M.Sc., Ph.D. selaku dosen pembimbing. Tak lupa pula saya ucapkan terima kasih kepada dosen penelaah yaitu Bapak Dr. Ir. Sumadi MS, Ibu Dr. Ir. Hj. Anne Nuraini, MS, dan Bapak Prof. Dr. Ir. Jajang Sauman Hamdani, MS.

\section{DAFTAR PUSTAKA}

Adnyesuari, AA, RH Murti, dan S Mitriwihardjo. 2015. Induksi partenokarpi pada tiga 
genotipe tomat dengan $\mathrm{GA}_{3}$. Jurnal Ilmu Pertanian. 18 (1): 56-62.

Cheniclet, C, WY Rong, M Causse, N Frangne, L Bolling, JP Carde, and JP Renaudin. 2005. Cell expansion and endore duplication show a large genetic variability in pericarp and contribute strongly to tomato fruit growth. Plant Physiology. 139: 1984-1994.

Choudhary, BR, MS Fageria, and RS Dhaka. 2002. Role growth hormones in Chillies - A review. Agric. Rev. 23(2): 145-148.

Choudhury, S, N Islam, MD Sarkar, and MA Ali. 2013. Growth and yield of summer tomato as influenced by plant growth regulators. International Journal of Sustainable Agriculture. 5(1): 25-28.

Das, SK, MD Sarkar, MJ Alam, MG Robbani, and MH Kabir. 2015. Influence of plant growth regulators on yield contributing characters and yield of bell pepper varieties. Journal of Plant Sciences. 10(2): 63-69.

Gardner, FP, RB Pearce, and RL Mitcheal. 1985. Phsyiology of Crop Plants. Iowa State University Press. Ames. Pp. 164-186.

Gelmesa, D, B Abebie, and L Desalegn. 2010. Effect of gibbelellic acid and 2,4dichlorophenoxyacetic acid spray on fruit yield and quality of tomato (Lycopersicon esculentum Mill.). Journal of Plant Breeding and Crop Science. 2(10): 316-324.

Gillaspy, G, HBDavid, and W Gruissem. 1993. Fruits: a developmental perspective. The Plant Cell. 5(10): 1439-1451.

Gunawan, I, Ferziana, dan R Kartika. 1986. Pengaruh jumlah daun dan pemberian $\mathrm{GA}_{3}$ terhadap hasil dan kadar sukrosa buah tanaman melon (Cucumis melo L.). Politeknik Pertanian Universitas Lampung. Jurnal Agrotropika. 1(1): 17-20.

Karim, MR, N Altaf, and S Sazzad. 2015. Improvement of summer tomato (Lycopersicon esculentum Mill.) production using 4-chlorophenoxy acetic acid. Journal of Bioscience and Agriculture Research. 4(2): 86-91.

Kishor, S, S Maji, ML Meena, H Deepa, DS Kishor, and S Kumar. 2017. Effect of plant bioregulators and chemicals on fruit physicochemical traits of pomegranate (Punica granatum L.) Cv. Bhagwa. Journal of Pharmacognosy and Phytochemistry. 6(4): 1573-1575.

Lemaire-Chamley, J Petit, V Garcia, D Just, P Baldet, and P Germain. 2005. Changes intranscriptional profiles are associated with early fruit tissue specialization in tomato. Plant Physiology. 139(2): 750-769.

Naeem, N, M Ishtiaq, P Khan, N Mohammad, J Khan, and B Jamiher. 2001. Effect of gibberellic acid on growth and yield of tomato cv. Roma. Online Journal of Biological Sciences. 1(6): 448-450.

Onggo, TM, Sumadi, dan R Fauziah. 2015. Pertumbuhan, hasil dan kualitas tomat cv. Marta-9 pada berbagai sistem budidaya dalam rumah plastik di dataran medium Jatinangor. Jurnal Kultivasi. 14(1): 37-42.

Sarkar, S, and B Ghosh. 2005. Effect of growth regulators on biochemical compostion of mango cv. Amrapali. Journal of Environmentand Ecology. 23(2): 379-380.

Serrani, JC, S Rafael, RR Omar, F Mariono, and Jose. 2007. Gibberellin regulation of fruit set and growth in tomato. Plant Physiology. 145 (1): 246-257.

Singh, J, AK Dwivedi, P Devi, and J Bajeli. 2019. Effect of plant growth regulators on growth and yield attributes of tomato (Solanum lycopersicom Mill.). International Journal of Current Microbiology and Applied Sciences. 8(1): 1635-1641.

Ullah, R, M Sajid, H Ahmad, M Luqman, M Razaq, G Nabi, S Fahad, and A Rab. 2014. Association of gibberellic acid $\left(\mathrm{GA}_{3}\right)$ with fruit set and fruit drop of sweet orange. Journal of Biology, Agriculture and Healthcare. 4(2): 54-59. 